УДК 378.147:[356.13+34](477)

DOI:

Ігор Перегняк, аспірант кафедри загальної педагогіки, дошкільної, початкової та спеціальної освіти Ізмаїльського державного гуманітарного університету

\title{
КРИТЕРІАЛЬНИЙ ПІДХІД ДО ФОРМУВАННЯ ПРАВОВОЇ КОМПЕТЕНТНОСТІ У ВІЙСЬКОВОСЛУЖБОВЦІВ ЗА КОНТРАКТОМ
}

У статті висвітлюється критеріальний підхід щодо формування професійної компетентності у військовослужбовиів за контрактом Державної прикордонної служби Украйни. На основі уточнення педагогічної сутності базового поняття, критеріями його сформованості визначено, таку сукупність: знаннєво-врегулювальний, діяльнісно-комунікативний, особистісно-іміджевий та рефлексивний. Схарактеризовано відповідні показники вияву визначених критеріїв, рівневу своєрідність (високий, достатній, базовий, недопустимий) та окреслено діагностувальний інструментарій.

Ключові слова: військовослужбовиі за контрактом; правова компетентність; показник; критерій, рівень сформованості.

Табл. 2. Літ. 12.

Ihor Perehnyak, Postgraduate Student of the General Pedagogics, Preschool, Primary and Special Education Department Izmayil State University of Humanities

\section{THE CRITERIAAPPROACH TO THE FORMATION OF LEGAL COMPETENCE IN THE MILITARY MEN UNDER THE CONTRACT}

The article deals with the criterial approach to the formation of professional competence in military servicemen under the contract at the Ukrainian State Border Guard Service. On the basis of the pedagogical essence of the basic concept, the criteria for its formation are determined: knowledge-regulative, activity-communicative, personimaginative and reflexive.

The knowledge-regulative criterion characterizes the level of assimilation by servicemen under the contract of legal knowledge: the understanding of the essence, content, aims and objectives of law enforcement activities; the possession of the knowledge system which is necessary for the effective performance of duties by position; the awareness of the methods and means of fulfilling duties.

The activity-communicative criterion is characterized by the ability to use the important knowledge professionally while implementing law-enforcement functions. The indicators of this criterion are the formation of professional law enforcement abilities; mastering of methods, ways and experience of independent solution of professional tasks.

The person-imaginative criterion is characterized by the presence of professionally important personal qualities that influence at the result of professional activity. The indicators of this criterion are the level of formation of qualities that are professionally important and necessary for the professional activity; the awareness of the significance of their activities; the desire to increase legal competence, self-perfection and self-development.

The reflexive criterion is to understand the preconditions, regularities and mechanisms of their professional activity, the social and individual way of existence of the military man. It provides the objective reflection and assessment of their own actions in the process of purposeful professional self-development which allows highlighting the components of success or identifying the causes of failure of their activities.

The appropriate indicators and their expression, the level of peculiarity (high, sufficient, basic, inadmissible) and diagnostic tools are also outlined.

Keywords: military men under the contract; legal competence; an indicator; criterion; a level of formation.

П остановка проблеми. За сучасних умов позитивної динаміки процесів глобалізації та євроінтеграції Державна прикордонна служба України (далі - ДПСУ) із року в рік нарощує співробітництво 3 правоохоронними відомствами інших країн, а українське законодавство більш інтенсивно інтегрується до норм міжнародного права. У зв'язку із чим особливої гостроти набуває постійне i систематичне підвищення рівня правової компетентності військовослужбовців у тому числі й тих, які служать за контрактом. Йдеться про категорію персоналу, що безпосередньо виконує фахово специфічні завдання з охорони державного кордону, які вимагають вчасної і компетентної реакції на зміни у вітчизняному законодавстві та постійно оновлювати набутий рівень правових знань. 


\section{КРИТЕРІАЛЬНИЙ ПЦДУДДО ФОРМУВАННЯПРАВОВОЇ КОМПЕТЕНТНОСТІ У ВІЙСЬКОВОСЛУЖБОВЦІВ ЗА КОНТРАКТОМ}

До того ж принципово важливою для зазначеної категорії персоналу не лише фундаментальна обізнаність у законодавчих та підзаконних актах, своїх правах і обов'язках за посадою, а й усвідомлювати свою роль і місце в загальній системі державного управління, вміти активно відстоювати та захищати інтереси громадян та України на державному кордоні саме ці якості мають бути притаманні особистості кожного військовослужбовця. А, отже, належне науково обгрунтоване діагностування рівня сформованості правової компетентності у військовослужбовців за контрактом створює можливості педагогічно вмотивовано впливати на динаміку досліджуваного процесу.

Аналіз останніх досліджень і публікацій. Педагогічне діагностування передбачає, насамперед, науково виваженого визначення критеріїв сформованості компетентності особистості. Означений ракурс проблеми виступає предметом дослідження військових педагогів (О. Барабанщиков, О. Діденко, В. Кикотя, А. Капустіна, О. Луцький, Н. Петренко, В. Ягупов та інші). Вчені, зокрема, вважають, що під критеріями сформованості ознченого явища слід розуміти сукупність ознак, що дозволяють визначити ступінь відповідності рівня сформованості в порівнянні між фактичними та стандартним вимогами.

При цьому враховувався доробок тих учених (В. Луговий, В. Кондрух, Л. Кустов, Т. Ліхачов, Н. Ничкало, М. Струнін), які здебільшого єдині у визначені, критеріального підходу, що базується на сучасному трактуванні поняття “критерій”. А йдеться, по-перше, про включення в науковий ужиток поняття “критерій” яке $\epsilon$ багатоаспектним; по-друге - застосування поняття “критерій” як ознаки, на підставі якої проводиться оцінка.

Метою статті с конкретизація основних критеріїв, показників, ознак їхнього вияву та визначення характеристики можливих рівнів сформованості саме правової компетентності у військовослужбовців за контрактом Державної прикордонної служби України.

Виклад основного матеріалу дослідження. Аналіз довідкової та психолого-педагогічної літератури засвідчує про те, що наукова спільнота під критерієм здебільшого розуміє ті якості явища, що відображають його суттєві характеристики, а тому підлягають оцінці [10]. Отже у загальному вигляді критерій - це важлива і визначальна ознака, яка характеризує якісні аспекти явища, його сутність. Показник становить кількісну характеристику явищ, які дають змогу зробити висновок про їхній стан у динаміці [11]. Водночас існують і дещо відмінні позиції у цьому плані.

Так, на думку О. Новікова, критерії мають задовольняти ряд ознак. Так, вони повинні бути об'єктивними (настільки, наскільки це можливо в педагогіці), дозволяти оцінювати досліджувану ознаку однозначно, адекватними, валідними, тобто оцінювати саме те, що дослідник хоче оцінити, нейтральними щодо досліджуваних явищ, а сукупність критеріїв повинна доволі повно охоплювати всі суттєві характеристики досліджуваного явища, процесу [7, 142].

С. Гончаренко, декламує, що при визначенні критерій слід ураховувати якість знань, яка передбачає співвідношення видів знань (закони, теорії, прикладні, методологічні, оцінювальні знання) з елементами змісту освіти й тим самим з рівнями їх засвоєння [3, 115].

Беручи до уваги вищезазначене, нами зроблено узагальнення про те, що критерій - це по суті педагогічно вмотивований набір конкретних ознак та якостей явища, об'єкта, предмета, які дають змогу визначити його стан, рівень розвитку та функціонування; поняття “критерій” за сугністю більш ширше, ніж показник, а останній є складовою частиною критерію (О. Діденко, І. Грязнов, М. Сметанський, Н. Петренко). У зв'язку із чим припускаємо, що за одним критерієм стоїть ціла низка показників. У довідниковій літературі термін “показник” визначається як ознака чого-небудь; явище або подія, на підставі яких можна робити висновки про перебіг якого-небудь процесу; кількісна характеристика властивостей процесу [2, 1024]. Отож приймаємо таку позицію якщо критерій це якості та властивості досліджуваного об'єкта, то показники - це міра сформованості того чи іншого показника [12].

Водночас відмічаємо, що критерій і показник $\epsilon$ взаємопов'язаними. Розуміємо, що обгрунтовано науковий вибір критерію у великій мірі обумовлює вірний вибір системи показників, a, відповідно, якість показника залежить від того, наскільки він повно і об'єктивно характеризує прийнятий критерій. Аналіз наукових джерел засвідчує про те, що у психодіагностиці, психології та педагогіці використовують суб'єктивні критерії. До числа таких критеріїв належать оцінки, судження, висновки про об'єкт дослідження, які зроблені експертом. Для більшої об'єктивізації такої оцінки одержані результати підрахунків усереднюються шляхом знаходження середнього арифметичного [6].

Вчені (О. Антонова та Л. Маслак) у наукових працях поділили на компоненти професійну 
компетентність офіцера радіоінженерної спеціальності, на зокрема, мотиваційно-ціннісний, когнітивний, комунікаційний та контрольно-оцінний $[8,162]$.

О. Жихорська у своєму доробку пропонує критерії професійної компетентності навчальнодопоміжного персоналу вищого навчального закладу розрізняти таки з них, як-от: когнітивний, діяльнісний, особистісний [5] .

Здійснений нами аналіз досліджень засвідчує, що існує багато різних підходів до визначення критеріїв і показників сформованості правової компетентності.

Так, опираючись на результатах обраного Я. Кічук проведення дослідницького підходу щодо діагностики компонентного складу та порогів сформованості у соціальних педагогів правової компетентності у процесі навчально-професійної діяльності в університеті [4]. Ми визначились у цьому аспекті власного дослідження.

До того ж ми врахували й інші підходи, що склались у цьому плані. Зокрема, точку зору В. Ситянін, який визначає рівні розвитку правової компетентності (адаптивний, нормативний, креативний), критерії (мотиваційно-ціннісний, когнітивний, поведінковий) i показники сформованості правової компетентності (правова орієнтація, правовий світогляд, правова поведінка) - компонентні і загальні [9].

В результаті проведеної систематичної роботи та врахувавши феноменологію правової компетентності саме військовослужбовців за контрактом, і саморефлексії власного досвіду, відповідно до структури досліджуваної компетентності нами були виділені наступні критерії: знаннєво-врегулювальний, діяльніснокомунікативний, особистісно-іміджевий та рефлексивний (табл. 1), які дають змогу визначити рівень сформованості правової компетентності військовослужбовців за контрактом.

Знаннєво-врегулювальний критерій характеризує рівень засвоєння військовослужбовцями за контрактом правових знань: розуміння сутності, змісту, цілей та завдань правозастосовної діяльності; володіння системою знань, необхідних для ефективного виконання обов' язків за посадою; обізнаність із методами та способами виконання обов'язків. Підготовка військовослужбовця за контрактом полягає у оволодінні професійними знаннями у правоохоронній сфері різними способами пізнання та практичної діяльності. Цей критерій характеризується тим, що діяльність військовослужбовця чітко врегульована нормами статутів, положень, посадових інструкцій, які створено відповідно до законодавства України. Показники визначаються наступними діагностувальними інструментами як анкетування, спостереження, бесіди, тестування, експертна оцінка, ділові та рольові ігри.

Ділльнісно-комунікативний критерій розкривається здапністювикористовуватипрофесійно важливі знання при здійсненні правозастосовних функцій. Показниками цього критерію є сформованість професійних правозастосовних умінь; оволодіння методами, способами і досвідом самостійного розв'язання професійних завдань. Також до цього критерію віднесемо знання законів комунікації, норм професійної деонтології, толерантного відношення, національно-специфічних особливостей спілкування; знання основних понять права. Інструментами діагностики $є$ спостереження, експертна оцінка, самооцінка, збір даних на основі вербальної комунікації, сфокусоване групове інтерв'ю, соціометричне опитування, ділові та рольові ігри, аналіз діяльності.

Особистісно-іміджевий критерій визначається наявністю професійно важливих особистісних якостей, які впливають на результат професійної діяльності. Показниками цього критерію є рівень сформованості професійно важливих і необхідних для здійснення професійної діяльності якостей; усвідомлення значущості своєї діяльності; прагнення до підвищення правової компетентності, самовдосконалення та саморозвитку.

Професія прикордонник відноситься до професій типу “Людина-Людина”. Прикордонник перший зустрічає і останній проводжає на кордоні громадян. I в значній мірі думка іноземців про нашу країну залежить від компетентності дій контролюючих органів на кордоні. А отже військовослужбовець за контрактом на державному кодоні має справляти приємне враження від себе починаючи із зовнішнього вигляду, культури поведінки, закінчуючи своїм рівнем компетентності. Завдяки чому формується позитивний імідж не тільки особистості, а і держави в цілому. Інструментами діагностики - $є$ спостереження, анкетування, самозвіти та звіти безпосередніх керівників та наставників, експертна оцінка.

Рефлексивний критерій вимагає осмислення військовослужбовцем передумов, закономірностей і механізмів власної професійної діяльності, соціального та індивідуального способу існування. Він передбачає здійснення об'єктивного осмислення й оцінки власних дій у процесі цілеспрямованого професійного саморозвитку, що дозволяє виокремити складові успіху або виявити 
Таблиця 1.

До характеристики діагностувального інструментарію сформованості правової компетентності військовослужбовців за контрактом

\begin{tabular}{|c|c|c|}
\hline $\begin{array}{l}\text { Структурно- } \\
\text { компонентний } \\
\text { склад базового } \\
\quad \text { поняття }\end{array}$ & Показники & $\begin{array}{c}\text { Педагогічні інструменти } \\
\text { діагностики }\end{array}$ \\
\hline $\begin{array}{c}\text { Знаннєво- } \\
\text { врегулювальний }\end{array}$ & $\begin{array}{l}\text { - розуміння сутності, змісту, цілей та завдань } \\
\text { правозастосовної діяльності; } \\
\text { - володіння системою знань, необхідних для } \\
\text { ефективного виконання обов'язків за посадою; } \\
\text { - обізнаність із методами та способами виконання } \\
\text { обов'язків; } \\
\text { - володіння базовими поняттями юриспруденції; } \\
\text { - знання законодавства України } 3 \text { прикордонних } \\
\text { питань та правових засад діяльності за посадою; } \\
\text { - знання керівних документів (статутів, положень, } \\
\text { посадових інструкцій тощо). }\end{array}$ & $\begin{array}{l}\text { анкетування, педагогічне } \\
\text { спостереження, бесіда, } \\
\text { тестування, експертна } \\
\text { оцінка, ділові та рольові } \\
\text { ігри. }\end{array}$ \\
\hline $\begin{array}{c}\text { Діяльнісно- } \\
\text { комунікативний }\end{array}$ & $\begin{array}{l}\text { - сформованість професійних правозастосовних } \\
\text { умінь; } \\
\text { - оволодіння методами, способами і досвідом } \\
\text { самостійного розв'язання професійних завдань. } \\
\text { - знання та дотримання законів комунікації, норм } \\
\text { професійної деонтології, толерантного відношення, } \\
\text { національно-специфічних особливостей спілкування; } \\
\text { знання основних понять права; } \\
\text { - вміння використовувати свої правозастосовні } \\
\text { знання в різних умовах службової діяльності; } \\
\text { - вміння застосовувати норми законодавства при } \\
\text { складанні процесуальних документів; } \\
\text { - вміння правильно кваліфікувати правопорушення, } \\
\text { що було вчинене на державному кордоні; } \\
\text { - вміння здійснювати заходи, щодо фото-, відео та } \\
\text { документальної фіксації правопорушення. }\end{array}$ & $\begin{array}{l}\text { педагогічне } \\
\text { спостереження, } \\
\text { експертна оцінка, } \\
\text { самооцінка, збір даних на } \\
\text { основі вербальної } \\
\text { комунікації, сфокусоване } \\
\text { групове інтерв’ю, } \\
\text { соціометричне } \\
\text { опитування, ділові та } \\
\text { рольові ігри, аналіз } \\
\text { діяльності. }\end{array}$ \\
\hline $\begin{array}{l}\text { Особистісно- } \\
\text { іміджевий }\end{array}$ & $\begin{array}{l}\text { - } \text { сформованість професійно важливих і необхідних } \\
\text { для здійснення професійної діяльності якостей; } \\
\text { - } \text { усвідомлення значущості своєї діяльності; } \\
\text { - } \quad \text { прагнення до подвищення пе правової } \\
\text { компетентності, самовдосконалення та саморозвитку; } \\
\text { - дотримання відомчих стандартів культури } \\
\text { поведінки в пунктах пропуску та на “зеленому” } \\
\text { кордоні; } \\
\text { - дотримання норм толерантності та професійної } \\
\text { деонтології; } \\
\text { - усвідомлення необхідності дотримуватись у своїй } \\
\text { поведінці норм права. }\end{array}$ & $\begin{array}{l}\text { педагогічне } \\
\text { спостереження, } \\
\text { анкетування, самозвіти та } \\
\text { звіти безпосередніх } \\
\text { керівників та } \\
\text { наставників, експертна } \\
\text { оцінка }\end{array}$ \\
\hline Рефлексивний & $\begin{array}{l}\text { - вміння свідомо контролювати результати своєї } \\
\text { діяльності, рівень власного розвитку, динаміку } \\
\text { особистісного зростання; } \\
\text { - прагнення до збагачення правових знань. }\end{array}$ & $\begin{array}{l}\text { Педагогічне } \\
\text { спостереження, } \\
\text { самооцінка }\end{array}$ \\
\hline
\end{tabular}

причини невдачі своєї діяльності. Реалізація цього критерію відбувається в умінні свідомо контролювати результати своєї діяльності, рівень власного розвитку, динаміки особистісного зростання: сформованість таких важливих якостей, як креативність, ініціативність, комунікативна відкритість, готовність до співпраці, співтворчості, толерантність, схильність до самоаналізу, здатність до імпровізації, творчого уявлення, передбачення. Активна рефлексивна позиція є необхідною передумовою саморозвитку фахівця, а їі відсутність практично повністю виключає можливість його як особистісного так і професійного саморозвитку. Інструментами діагностики - $є$ спостереження, самооцінка.

Діагностика критеріїв та показників правової 
Таблиця 2.

Рівнева характеристика сформованості правової компетентності військовослужбовців за контрактом

\begin{tabular}{|c|c|c|c|}
\hline \multicolumn{4}{|c|}{ Знаннєво-врегулювальний критерій } \\
\hline $\begin{array}{c}\text { Припустимий } \\
\text { (1-3 балів) }\end{array}$ & $\begin{array}{c}\text { Базовий } \\
\text { (4-6 балів) }\end{array}$ & $\begin{array}{l}\text { Достатній } \\
\text { (7-9 балів) }\end{array}$ & $\begin{array}{c}\text { Високий } \\
\text { (10-12 балів) }\end{array}$ \\
\hline $\begin{array}{l}\text { - слабка орієнтація в } \\
\text { цілях та завданнях } \\
\text { правозастосовної } \\
\text { діяльності; } \\
\text { - поверхневе } \\
\text { розуміння необхідності } \\
\text { використовувати } \\
\text { правові знання на } \\
\text { практиці; } \\
\text { - поверхневий рівень } \\
\text { володінні } \\
\text { законодавством } \\
\text { України } \\
\text { прикордонних питань; } \\
\text { - не знання вимог } \\
\text { нормативно-правових } \\
\text { документів, статутів, } \\
\text { положень, посадових } \\
\text { обов'язків тощо. }\end{array}$ & $\begin{array}{l}\text { - неповна орієнтація в } \\
\text { цілях та завданнях } \\
\text { правозастосовної } \\
\text { діяльності; } \\
\text { - часткове розуміння } \\
\text { необхідності } \\
\text { використовувати } \\
\text { правові знання на } \\
\text { практиці; } \\
\text { - на } \\
\text { якісному недостатньо } \\
\text { володіння рівні } \\
\text { законодавством } \\
\text { України } \\
\text { прикордонних питань; } \\
\text { - слабкі знання вимог } \\
\text { нормативно-правових } \\
\text { документів, статутів, } \\
\text { положень, посадових } \\
\text { обов'язків тощо. }\end{array}$ & $\begin{array}{l}\text { - задовільна орієнтація } \\
\text { в цілях та завданнях } \\
\text { правозастосовної } \\
\text { діяльності; } \\
\text { - є в цілому розуміння } \\
\text { необхідності } \\
\text { використовувати } \\
\text { правові знання на } \\
\text { практиці; } \\
\text { - на доброму рівні } \\
\text { володіння } \\
\text { законодавством } \\
\text { України } \\
\text { прикордонних питань; } \\
\text { - добре знає вимоги } \\
\text { нормативно-правових } \\
\text { документів, статутів, } \\
\text { положень, посадових } \\
\text { обов'язків тощо. }\end{array}$ & $\begin{array}{l}\text { - добра орієнтація в } \\
\text { цілях та завданнях } \\
\text { правозастосовної } \\
\text { діяльності; } \\
\text { - у повній мірі } \\
\text { розуміння необхідності } \\
\text { використовувати } \\
\text { правові знання на } \\
\text { практиці; } \\
\text { - повне } \\
\text { законодавством володіння } \\
\text { України } \\
\text { прикордонних питань; } \\
\text { - відмінно знає вимоги } \\
\text { нормативно-правових } \\
\text { документів, статутів, } \\
\text { положень, посадових } \\
\text { обов’язків тощо. }\end{array}$ \\
\hline \multicolumn{4}{|c|}{ Діяльнісно-комунікативний критерій } \\
\hline $\begin{array}{c}\text { Припустимий } \\
\text { (1-3 балів) }\end{array}$ & $\begin{array}{c}\text { Базовий } \\
\text { (4-6 балів) }\end{array}$ & $\begin{array}{l}\text { тній } \\
\text { алів) }\end{array}$ & $\begin{array}{l}\text { кий } \\
\text { балів) }\end{array}$ \\
\hline $\begin{array}{l}\text { - недостатня } \\
\text { розвиненість } \\
\text { правозастосовних } \\
\text { вмінь; } \\
\text { - неточність зри } \\
\text { виконанні завдань за } \\
\text { призначенням; } \\
\text { - неможливість } \\
\text { вирішення завдань } \\
\text { самостійно; } \\
\text { - незадовільний рівень } \\
\text { комунікабельності. }\end{array}$ & 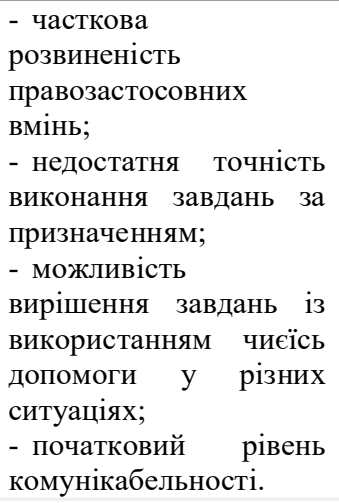 & $\begin{array}{l}\text { - достатня } \\
\text { розвиненість } \\
\text { правозастосовних } \\
\text { вмінь; } \\
\text { - точне виконання } \\
\text { завдань } \\
\text { призначенням; } \\
\text { - можливість частково } \\
\text { самостійного } \\
\text { вирішення завдань у } \\
\text { різних ситуаціях; } \\
\text { - середній рівень } \\
\text { комунікабельності. }\end{array}$ & $\begin{array}{l}\text { - добра розвиненість } \\
\text { правозастосовних } \\
\text { вмінь; } \\
\text { - якісне та точне } \\
\text { виконання завдань за } \\
\text { призначенням; } \\
\text { - можливість } \\
\text { самостійного } \\
\text { вирішення завдань у } \\
\text { різних ситуаціях; } \\
\text { - високий ківень } \\
\text { комунікабельності. }\end{array}$ \\
\hline \multicolumn{4}{|c|}{ Особистісно-іміджевий критерій } \\
\hline $\begin{array}{c}\text { Припустимий } \\
\text { (1-3 балів) }\end{array}$ & $\begin{array}{c}\text { Базовий } \\
\text { (4-6 балів) }\end{array}$ & $\begin{array}{l}\text { тній } \\
\text { алів) }\end{array}$ & $\begin{array}{c}\text { Високий } \\
\text { (10-12 балів) }\end{array}$ \\
\hline $\begin{array}{l}\text { - недостатня } \\
\text { сформованість } \\
\text { професійно-правових } \\
\text { якостей особистості; } \\
\text { - недостатнє } \\
\text { усвідомлення } \\
\text { важливості } \\
\text { діяльності; своєї } \\
\text { - слабкий пізнавальний } \\
\text { інтерес у прагненні } \\
\text { підвищити свого рівня } \\
\text { правових знань; } \\
\text { - слабке уявлення про } \\
\text { культуру поведінки та }\end{array}$ & 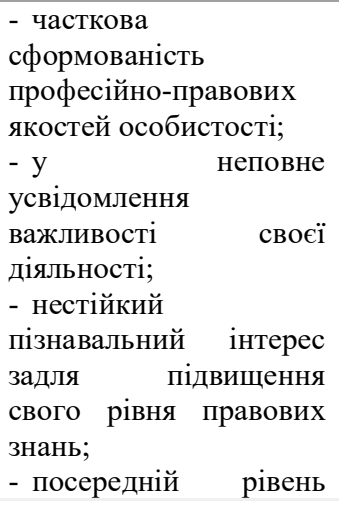 & $\begin{array}{l}\text { - добра сформованість } \\
\text { професійно-правових } \\
\text { якостей особистості; } \\
\text { - у великій мірі } \\
\text { усвідомлення } \\
\text { важливості } \\
\text { діяльності; своєї } \\
\text { - періодична робота } \\
\text { над підвищенням рівня } \\
\text { правових знань; } \\
\text { - добрий рівень } \\
\text { культури та } \\
\text { професійного етикету. }\end{array}$ & $\begin{array}{l}\text { - повна сформованість } \\
\text { професійно-правових } \\
\text { якостей особистості; } \\
\text { - повне усвідомлення } \\
\text { важливості } \\
\text { діяльності; своєї } \\
\text { - постійна робота над } \\
\text { підвищенням рівня } \\
\text { правових знань; } \\
\text { - високий } \\
\text { культури рівень } \\
\text { професійного етикету. }\end{array}$ \\
\hline
\end{tabular}




\begin{tabular}{|c|c|c|c|}
\hline \multicolumn{4}{|r|}{ Продовження таблиці 2.} \\
\hline \multicolumn{4}{|c|}{ Рефлексивний критерій } \\
\hline $\begin{array}{c}\text { Припустимий } \\
\text { (1-3 балів) }\end{array}$ & $\begin{array}{c}\text { Базовий } \\
\text { (4-6 балів) }\end{array}$ & $\begin{array}{l}\text { Достатній } \\
\text { (7-9 балів) }\end{array}$ & $\begin{array}{c}\text { Високий } \\
\text { (10-12 балів) }\end{array}$ \\
\hline $\begin{array}{l}\text { - відсутній } \\
\text { самоконтроль над } \\
\text { своєю діяльністю; } \\
\text { - відсутній контроль за } \\
\text { саморозвитком; } \\
\text { - повна відсутність } \\
\text { прагнення } \\
\text { збагачення правових } \\
\text { знань. }\end{array}$ & $\begin{array}{l}\text { - посередній } \\
\text { самоконтроль над } \\
\text { своєю діяльністю; } \\
\text { - несистемний } \\
\text { контроль за } \\
\text { саморозвитком; } \\
\text { - періодичне } \\
\text { прагнення до } \\
\text { збагачення правових } \\
\text { Знань. }\end{array}$ & $\begin{array}{l}\text { - добрий самоконтроль } \\
\text { над своєю діяльністю; } \\
\text { - на доброму рівні } \\
\text { контроль за } \\
\text { саморозвитком; } \\
\text { - стабільне прагнення } \\
\text { до збагачення правових } \\
\text { знань. }\end{array}$ & $\begin{array}{l}\text { - повний свідомий } \\
\text { контроль над своєю } \\
\text { діяльністю; } \\
\text { - повний контроль за } \\
\text { саморозвитком; } \\
\text { - високе прагнення до } \\
\text { збагачення правових } \\
\text { знань. }\end{array}$ \\
\hline
\end{tabular}

компетентності військовослужбовців за контрактом безпосередньо пов'язана із встановленням діагностики розвитку об'єкта дослідження.

Вчені (Н. Авшенюк, Т. Десятов, Л. Дяченко, Н. Постригач, Л. Пуховська, О. Сулима) вважають, що оцінювання в рамках навчання, побудованого на компетентності, спрямоване на вимірювання засвоєної цілісної компетентності, а не окремих знань i вмінь. У випадку недостатності представлених фахівцем свідчень, він отримує консультації щодо того, на що варто звернути увагу і що вдосконалювати. За своєю суттю оцінка може бути або позитивною - “уміє робити”, або негативною - “ще не вміє” $[1,221]$.

Далі, відповідно до логіки наукової роботи, $є$ доцільним виділення чотирьох рівнів сформованості професійної компетентності: високий, достатній, базовий, припустимий (табл. 2).

У дослідженні рівнів, що визначено за відповідними критеріями, окрім кількісної характеристики, нами застосовано - якісну, відповідно до шкільної дванадцятибальної системи оцінювання. Оцінювання у діапазоні 10 - 12 балів відповідає високому рівню сформованості відповідного критерію правової компетентності, 7 - 9 - достатньому, 4 - 6 базовому та 1-3 - припустимому.

Висновки дослідження. В результаті проведеного аналізу наукового фонду, практики, що склалась у ракурсі порушеної проблеми встановлені, що основні критерії сформованості зазначеної компетентності. А саме, знаннєвоврегулювальний (характеризує рівень сформованості правових знань), діяльнісно-комунікативний (характеризує уміння використовувати правничі знання у службовій діяльності), особистісноіміджевий (характеризує рівень правової обізнаності, увібрання у особистісну сферу правових норм, ціннісне ставлення до норм права та службового етикету), а також рефлексивний (характеризуе рівень самосвідомого виконання правозастосовних функиій).

Представлено діагностичний апарат для визначення рівня сформованості правової компетентності військовослужбовців за контрактом вітчизняного прикордонного відомства. Сформованість правової компетентності військовослужбовців за контрактом ДПСУ може проявлятися на високому, достатньому, базовому і припустимому рівнях

Перспективи подальших розвідок у даному напрямку. Вищезазначений дослідницький підхід розкриває можливості цілеспрямованості освітніх зусиль щодо конструктивного розвитку правової компетентності у військовослужбовців Державної прикордонної служби України як у навчальних закладах відомства, так органів охорони державного кордону.

\section{ЛІТЕРАТУРА}

1. Авшенюк Н.М. Компетентнісний підхід до педагогів узарубіжних країнах: теорія та практика: монографія / [Н.М. Авшенюк, Т.М. Десятов, Л.М. Дяченко, Н.О. Постригач, Л.П. Пуховська, О.В. Сулима]. Кіровоград, 2014. С. 280.

2. Великий тлумачний словник сучасної української мови (з дод. і допов.) / Уклад. і голов. ред. В.Т. Бусел. Київ, 2005. 1728 с.

3. Гончаренко С. У. Український педагогічний словник. Київ. 1997. 376 с.

4. Кічук Я. В. Правова компетентність майбутнього соціального педагога: теорія $і$ практика: Монографія. Ізмаїл, 2009. - 244 с.

5. Критерії, показники та рівні сформованості професійної компетентності навчальнодопоміжного персоналу вищого навчального закладу/ О. Жихорська/ Science and Education a New Dimension. Pedagogy and Psychology, III(34), Issue: 69, 2015/URL: http://seanewdim.com/uploads/ 3/4/5/1/34511564/zhykhorska_o._criteria_i ndicators_a nd_levels_of_formed_of_professional 
_competence of_support_staff_of higher_education_institutions.pdf] $\overline{16} .08 .201 \overline{8}$

6. Курлянд 3. Н. Методика діагностики i формування професійної усталеності майбутніх учителів. Одеса, 1993. 242 с.

7. Новиков А. М., Новиков Д. А. Методология научного исследования. Москва, 2010. 280 с.

8. Професійна педагогічна освіта: компетентнісний підхід: монографія/ за ред. О.А. Дубасенюк. Житомир, 2011. 412 с., с.162.

9. Ситянін В. В. Формування правової компетентності науково-педагогічних працівників вищої школи: автореф. дис. канд. пед. наук : 13.00.04. ДВНЗ “Університет менеджменту освіти” Національної академії педагогічних наук України. Київ, 2010. 21 с.

10. Толковый словарь Ушакова. URL: 16.08.2018: https://gufo.me/dict/social_dict/ Критерий

11. Улятовская Е. А. Подготовка будущих учителей по активизации самостоятельной познавательной деятельности младших школьников: Автореф. дис. канд. пед. наук.: 13.00.04. Измаил, 1998. 21 с.

12. Этнопедагогическая компетентность педагога: критерии, показатели и уровни сформированности / В.К. Кузьмин, Д.А. Крылов, В.А. Комелина, Н.В. Кузьмин. // Современные проблемы науки и образования. 2014. URL: 12.08.2018: http://www.science-education.ru/119$\underline{14991 .}$

\section{REFERENCES}

1. Avsheniuk, N., Desiatov, T., Diachenko, L., Postryhach, N., Pukhovska, L. \& Sulyma, O. (2014). Kompetentnisnyi pidkhid do pedahohiv u zarubizhnykh krainakh: teoriia ta praktyka [Competent approach to teachers in foreign countries: theory and practice]. Kirovohrad, 280 p. [in Ukrainian].

2. Busel, V. (2005). Velykyi tlumachnyi slovnyk suchasnoi ukrainskoi movy [Great explanatory dictionary of modern Ukrainian language]. Irpin, 1728 p. [in Ukrainian].

3. Honcharenko, S. (1997). Ukrainskyi pedahohichnyi slovnyk [Great Ukrainian pedagogical dictionary]. Kyiv, 376 p. [in Ukrainian].

4. Kichuk, Ya. (2009). Pravova kompetentnist maibutnoho sotsialnoho pedahoha: teoriia $i$ praktyka [Legal competence of the future social pedagogue: theory and practice]. Izmail, 244 p. [in Ukrainian].

5. Zhykhorska, O. (2015). Kryterii, pokaznyky ta rivni sformovanosti profesiinoi kompetentnosti navchalno-dopomizhnoho personalu vyshchoho navchalnoho zakladu [Criteria, indicators and levels of formation of professional competence of the teaching and support staff of the higher educational establishment]. Available at: http://seanewdim.com/ uploads/3/4/5/1/34511564/zhykhorska_o._criteria_i ndicators_and_levels_of_formed_of_professional _competence_of_support_staff of_ higher_education_institutions.pdf]

6. Kurliand, Z. (1993). Metodyka diahnostyky $i$ formuvannia profesiinoi ustalenosti maibutnikh uchyteliv [Methodology of diagnostics and formation of professional tiredness of future teachers]. Odessa, 242 p. [in Ukrainian].

7. Novikov, A. \& Novikov, D. (2010). Metodologiya nauchnogo issledovaniya [Research Methodology]. Moscow, 280 p. [in Russian].

8. Dubaseniuk, O. (2011). Profesiina pedahohichna osvita: kompetentnisnyi pidkhid [Professional teaching education: a competency approach]. Monograph. Zhytomyr, 412 p. [in Ukrainian].

9. Sytianin, V. (2010). Formuvannia pravovoi kompetentnosti naukovo-pedahohichnykh pratsivnykiv vyshchoi shkoly [Formation of legal competence of scientific and pedagogical workers of higher education]. Kyiv. Extended abstract of candidate's thesis. University of management education of the National academy of pedagogical sciences of Ukraine, 21 p. [in Ukrainian].

10. Tolkovyy slovar Ushakova [The Ushakov explanatory dictionary]. Available at: https://gufo.me/ dict/social_dict/Критерий. [in Russian].

11. Ulyatovskaya, Ye. (1998). Podgotovka budushchikh uchiteley po aktivizatsii samostoyatelnoy poznavatelnoy deyatelnosti mladshikh shkolnikov [Training future teachers to enhance the independent cognitive activity of younger students]. Izmail. Extended abstract of candidate's thesis. 21 p. [in Russian].

12. Kuzmin, V., Krylov, D., Komelina, V. \& Kuzmin, N. Etnopedagogicheskaya kompetentnost pedagoga: kriterii, pokazateli i urovni sformirovannosti [Ethnopedagogical competence of a teacher: criteria, indicators and levels of formation]. Available at: http:/ /www.science-education.ru/119-14991. [in Russian].

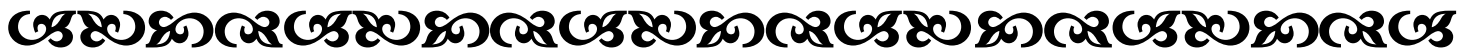

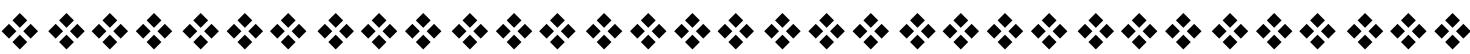

